\title{
Clinical Analysis of restrictive strabismus secondary to ophthalmic surgery
}

\section{Lili Guo}

Peking University People's Hospital

Zhihua Zhao

Hebei General Hospital

\section{Zequn Miao}

Peking University People's Hospital

\section{Qianru Ouyang}

Peking University People's Hospital

\section{Xin Xu}

Peking University People's Hospital

Lejin Wang ( $\square$ yqsi331@163.com)

Peking University People's Hospital

\section{Research Article}

Keywords: Secondary restrictive strabismus, diplopia, surgery

Posted Date: April 20th, 2021

DOI: https://doi.org/10.21203/rs.3.rs-436997/v1

License: @ (i) This work is licensed under a Creative Commons Attribution 4.0 International License. Read Full License 


\section{Abstract}

Background: This study aimed to report the clinical characteristics and surgical methods of restrictive strabismus secondary to ophthalmic surgery.

Methods: This retrospective case series covered 14 restrictive strabismus cases secondary to ophthalmic surgery. After evaluation of the clinical history and the basic ophthalmological findings, the following parameters were examined: squint angles (prism with alternative cover test, Krimsky's test or Maddox cross), ocular motility, duction test and the forced duction test. All paitients underwent surgery, the strabismus surgery included the excision of adhesions and scar tissue, adhesiolysis, medial and lateral ligaments separated, repositioning of extraocular muscles (according to the degree of deviations). We described the clinical characteristics and evaluated the surgical results in strabismus eyes.

Results: All patients were satisfied with the results of surgery, obtained anatomical reduction and partial functional recovery. In nine cases with preoperative diplopia, eight cases had no diplopia after surgery and one patient's diplopia disappeared after the secondary surgery. The other five cases without preoperative diplopia, but had restricted ocular motility, which improved significantly than before surgery.

Conclusions: Orbital surgery, trauma, conjunctival surgery, strabismus surgery and so on, can lead to secondary restrictive strabismus surgery. Strabismus surgical treatments including the full removal of the muscles around the scar, adhesiolysis, medial and lateral ligaments separated, eye muscle surgery, can provide excellent results and patient's satisfaction.

\section{Background}

Secondary restrictive strabismus is unconcomitant strabismus, due to the mechanical action of adherences between extraocular muscle and surrounding connective tissue, conjunctival and moderate ligament, bulbar conjunctival scarring after pterygium excision [1], cosmetic wide conjunctivectomy [2], scleral buckle procedure [3], and orbital surgery [4-8], limited the eyeball movements and generated strabismus. Its mechanisms include sensory disturbances after surgery, surgical scars, bleeding, direct muscle injury, myotoxicity caused by the injection of local anesthesia or antibiotics, abnormal position of restrictive extraocular muscles caused by implants, and so on [2, 9-11]. It has aroused the attention of ophthalmologist because of its complexity. Clinical manifestations include diplopia, dyskinesia, abnormal movement, anisometropia and compensatory head position. If it occurs in children childhood, can also lead to amblyopia. The overall incidence of secondary restrictive strabismus has not been reported. The corrective surgery has its difficulty and there is no report about the surgery choice and specific methods of the surgery. Therefore, this article retrospectively analyzes the clinical data of the patient diagnosed secondary restrictive strabismus after ophthalmic surgery in our hospital during April 2015 to September 2015, and analyzed its causes, clinical features and surgical methods.

\section{Materials And Methods}

1. General Information: The study included 14 patients ( 6 women and 8 men) with a mean age of 32.7 years,patients were followed up for 3 months. 14 cases of secondary restrictive strabismus, in which include 2 cases secondary to thyroid orbitopathy surgery and strabismus surgery, 4 cases secondary to orbital fracture surgery, one case secondary to orbital tumors surgery, 3 cases secondary to strabismus surgery, one case secondary to conjunctivochalasis surgery, two cases secondary to conjunctival trauma suture surgery, one case secondary to traumatic cataract surgery. The recruitment and research protocols were reviewed and approved by the Institutional ethics commission. 
2. Methods: After evaluation of the clinical history and the basic ophthalmological findings,the following parameters were examined: squint angles (prism with alternative cover test, Krimsky's test or Maddox cross), duction test and the forced duction test monocular and binocular movements and the characteristics of strabismus. All included patients had ophthalmologic motility exams testing ductions of each eye in four cardinal gaze positions: abduction, adduction, supraduction, and infraduction. Motility in each gaze position was graded on a commonly used scale of 0 to -4 , with 0 signifying no restriction and -4 indicating an inability to pass the midline in a particular direction. The remaining points on the scale represent further reduction in approximately $25 \%$ increments in between normal motility and inability to pass midline [12]. Figure 1 depicts an example of this motility scale for supraduction.

Duction test and the forced duction test to examine the ocular motility, eyeball movements limited level: (1) mild: some limited movement in a direction independent, passive stretch of the eye can place; (2) moderate: a direction completely independent movement restricted when the eye can not be completely passive stretch in place; (3) severe: passive stretch completely restricted. All preoperative clinical data of included patients is shown in Table 1. 
Table 1

uPreoperative clinical data

\begin{tabular}{|c|c|c|c|c|c|c|c|c|}
\hline No. & Sex & Age & Eye & $\begin{array}{l}\text { Eye ball } \\
\text { Motility }\end{array}$ & $\begin{array}{l}\text { Duction } \\
\text { test }\end{array}$ & Vision & Cause of disease & Symptom \\
\hline 1 & M & 57 & OS & $\begin{array}{l}\text { Supraduction- } \\
3 \\
\text { Abduction-3 }\end{array}$ & Severe & 1.0 & $\begin{array}{l}\text { Thyroid- } \\
\text { AssociatedOphthalmopathy(TAO) } \\
\text { surgery } 1 \text { year ago }\end{array}$ & Diplopia \\
\hline 2 & M & 77 & os & Abduction-3 & Severe & 0.6 & $\begin{array}{l}\text { Conjunctivochal-asis before } 3 \\
\text { months }\end{array}$ & Diplopia \\
\hline 3 & M & 22 & OD & Addution-2 & Mild & 0.2 & $\begin{array}{l}\text { Trauma and IOL implantation } \\
\text { before } 10 \text { years }\end{array}$ & Exotropia \\
\hline 4 & $\mathrm{~F}$ & 33 & OD & $\begin{array}{l}\text { Abduction - } 3 \\
\text { Supraduction- } \\
3\end{array}$ & Severe & 1.0 & $\begin{array}{l}\text { Orbital fractures, superior, inferior, } \\
\text { medial rectus surgery many times } \\
1 \text { year ago }\end{array}$ & Diplopia \\
\hline 5 & M & 85 & OD & $\begin{array}{l}\text { Supraduction- } \\
3\end{array}$ & Severe & 0.8 & Rectus fractures 1 year ago & Diplopia \\
\hline 6 & $\mathrm{~F}$ & 25 & os & Abduction-3 & Mild & 1.0 & $\begin{array}{l}\text { Eye strabismus surgery } 10 \text { years } \\
\text { ago }\end{array}$ & Esotropia \\
\hline 7 & $\mathrm{~F}$ & 28 & os & $\begin{array}{l}\text { Supraduction- } \\
3\end{array}$ & Severe & 1.0 & $\begin{array}{l}\text { Orbital tumor removal surgery } 2 \\
\text { years ago }\end{array}$ & Diplopia \\
\hline 8 & M & 17 & OD & Abduction-3 & Mild & 0.01 & $\begin{array}{l}\text { Exotropia strabismus surgery } 10 \\
\text { years ago }\end{array}$ & Esotropia \\
\hline 9 & $M$ & 10 & os & Adduction-3 & Severe & 1.0 & $\begin{array}{l}\text { Medial orbital wall fracture } 1 \text { year } \\
\text { ago }\end{array}$ & $\begin{array}{l}\text { Exotropia } \\
\text { Diplopia }\end{array}$ \\
\hline 10 & $\mathrm{~F}$ & 3 & OD & $\begin{array}{l}\text { Supraduction- } \\
3\end{array}$ & Severe & 0.05 & $\begin{array}{l}\text { Conjunctiva and inferior rectus } \\
\text { (IR) muscle damaged } 1.5 \text { years } \\
\text { ago }\end{array}$ & $\begin{array}{l}\text { Strabismus } \\
\text { Amblyopia }\end{array}$ \\
\hline 11 & $\mathrm{~F}$ & 9 & OU & $\begin{array}{l}\text { OS } \\
\text { Abduction-2 }\end{array}$ & Mild & 1.0 & $\begin{array}{l}\text { Double eye underwent exotropia } \\
\text { surgery twice } 4 \text { years ago }\end{array}$ & Esotropia \\
\hline 12 & M & 10 & OD & $\begin{array}{l}\text { Supraduction- } \\
2\end{array}$ & Severe & 1.0 & $\begin{array}{l}\text { Orbital fractures surgery } 1 \text { year } \\
\text { ago }\end{array}$ & $\begin{array}{l}\text { Exotropia } \\
\text { Diplopia }\end{array}$ \\
\hline 13 & M & 49 & OD & $\begin{array}{l}\text { Supraduction- } \\
3 \\
\text { Infraduction-4 }\end{array}$ & Severe & 1.0 & $\begin{array}{l}\text { conjunctival trauma suture } \\
\text { surgery } 9 \text { days ago }\end{array}$ & Diplopia \\
\hline 14 & $\mathrm{~F}$ & 32 & OU & $\begin{array}{l}\text { OD } \\
\text { Abduction-3 } \\
\text { OS } \\
\text { Abduction-2 }\end{array}$ & Moderate & $\begin{array}{l}1.0 \\
1.0\end{array}$ & $\begin{array}{l}\text { TAO surgery, and strabismus } \\
\text { surgery } 9 \text { months ago }\end{array}$ & $\begin{array}{l}\text { Diplopia, } \\
\text { Esotropia, } \\
\text { Mild face } \\
\text { side left }\end{array}$ \\
\hline
\end{tabular}


3. Surgical indications: (1) In a functional eye position (in primary position and down reading gaze) appear persistent binocular diplopia, Duction test is positive, diplopia and eyeball movements have been stable for more than six months, or since the last surgery two weeks or less. (2) horizontal strabismus $\geq 15$ prism diopters(PD), vertical strabismus $\geq 10$ PD, and / or associated with compensatory head position. (3) The wish to undergo surgery because of an aesthetically unacceptable strabismus, or amblyopia, leading to undergo strabismus surgery to create conditions for the further treatment of amblyopia.

4. Surgical methods: The strabismus surgery included the excision of adhesions and scar tissue, adhesiolysis, disconnection of medial and lateral ligaments, reposition of extraocular muscles (according to the degree of deviations).

\section{Results}

1. Extraocular muscle and its around connective tissue adhesions, conjunctival scarring were seen in patients surgery, some of them accompanied by muscle atrophy and fibrosis. Two cases secondary to the first strabismus surgery were accompanied by adhesion of lateral rectus (LR) and inferior oblique (IO) muscle.

2. All 14 patients showed a preoperative horizontal squint angles range of 100 to 20 PD, average 39.8 PD, vertical squint angles is range of 20 to $8 \mathrm{PD}$, average 12.2 PD. Postoperative horizontal squint angles averaged 3.1PD, squint angles averaged 0.9 PD. 13 patients achieved good results after the first surgery, and 1 patient obtained good results after the secondary surgery. All patients were satisfied with the results of surgery,obtained anatomical reduction and partial functional recovery. In nine cases with preoperative diplopia, five cases had no diplopia in full field after the first surgery, three cases had no diplopia in functional eye position (in primary position and down reading gaze), one patient's diplopia disappeared after the secondary surgery. The other five cases without preoperative diplopia, but had restricted ocular motility, which was improved significantly after surgery (Table 2). 
Table 2

Patients with surgery and postoperative data

\begin{tabular}{|c|c|c|c|c|c|}
\hline No. & $\begin{array}{l}\text { Prism } \\
\text { with } \\
\text { alternative } \\
\text { cover test, } \\
\text { Krimsky's } \\
\text { test(PD) }\end{array}$ & $\begin{array}{l}\text { Prism } \\
\text { with } \\
\text { Maddox } \\
\text { cross } \\
\text { (PD) }\end{array}$ & Surgical approach & $\begin{array}{l}\text { Postoperative } \\
\text { follow-up time } \\
\text { (3 months) }\end{array}$ & $\begin{array}{l}\text { Postoperative } \\
\text { squint } \\
\text { angles(PD) }\end{array}$ \\
\hline 1 & $+30 \mathrm{R} / \mathrm{L} 20$ & $\begin{array}{l}\text { Level: } \\
+30 \text {, } \\
\text { Increasing } \\
\text { in left }\end{array}$ & $\begin{array}{l}\text { The left medial rectus (MR) and IR } \\
\text { underwent the temperance ligament } \\
\text { separation, release of adhesions, scar } \\
\text { removal, } \\
+7 \mathrm{~mm} \text { of } \mathrm{MR} \text { recession and } 5 \mathrm{~mm} \\
\text { suspension } \\
+5 \mathrm{~mm} \text { of IR recession and } 5 \mathrm{~mm} \\
\text { suspension }\end{array}$ & $\begin{array}{l}\text { Hirschberg test: } \\
\text { ortho, no diplopia at } \\
\text { primary and down } \\
\text { gaze } \\
\text { supraduction-2 }\end{array}$ & -2 \\
\hline 2 & +30 & $\begin{array}{l}\text { Right + 8, } \\
\text { Below + } \\
25, \\
\text { Left + } 25\end{array}$ & $\begin{array}{l}\text { The left LR and MR exploration, scar } \\
\text { removal, temperance ligament } \\
\text { separation, release of adhesions } \\
+6 \mathrm{~mm} \text { of LR shortening. }\end{array}$ & $\begin{array}{l}\text { Hirschberg test: } \\
\text { ortho, no diplopia at } \\
\text { primary and down } \\
\text { gaze }\end{array}$ & -2 \\
\hline 3 & -80 & & $\begin{array}{l}\text { Scar around of right MR resection, } \\
\text { temperance ligament separation, release } \\
\text { of adhesions }+5 \mathrm{~mm} \text { of MR shortening } \\
\text { and } 7 \mathrm{~mm} \text { of LR recession. }\end{array}$ & $\begin{array}{l}\text { Hirschberg test: } \\
\text { ortho, motion } \\
\text { normally }\end{array}$ & -4 \\
\hline 4 & $+14 \mathrm{~L} / \mathrm{R} 18$ & +9L/R12 & $\begin{array}{l}\text { Scar around of right LR and IR resection, } \\
\text { adhesion releasion, temperance ligament } \\
\text { separation }+5 \mathrm{~mm} \text { of IR recession. }\end{array}$ & $\begin{array}{l}\text { Hirschberg test: } \\
\text { ortho, no diplopia at } \\
\text { primary and down } \\
\text { gaze, motion } \\
\text { improved }\end{array}$ & -2 \\
\hline 5 & $-10 \mathrm{~L} / \mathrm{R} 12$ & & $\begin{array}{l}\text { Scar around the right in IR resected, } \\
\text { adhesion release, temperance ligament } \\
\text { separation }+3 \mathrm{~mm} \text { of IR recession and } \\
5 \mathrm{~mm} \text { of right MR recession. }\end{array}$ & $\begin{array}{l}\text { Hirschberg test: } \\
\text { ortho } \\
\text { No diplopia }\end{array}$ & $-2 \mathrm{~L} / \mathrm{R} 1$ \\
\hline 6 & +100 & & $\begin{array}{l}\text { Get rid of the scar around left MR, } \\
\text { adhesion release, temperance ligament } \\
\text { separation + MR fixed } 11 \mathrm{~mm} \text { at the rear } \\
\text { edge of the cornea }\end{array}$ & $\begin{array}{l}\text { Hirschberg test: } \\
\text { ortho, } \\
\text { Motion normally }\end{array}$ & +3 \\
\hline 7 & L/R14 & $\begin{array}{l}\text { Front } \\
\text { L/R14 } \\
\text { Below } \\
\text { L/R22 }\end{array}$ & $\begin{array}{l}\text { Scar around contracted left superior } \\
\text { rectus (SR) excision, adhesion release, } \\
\text { temperance ligament separation }+5 \mathrm{~mm} \\
\text { of SR recession. }\end{array}$ & $\begin{array}{l}\text { Hirschberg test: } \\
\text { ortho, no diplopia }\end{array}$ & L/R1 \\
\hline 8 & +90 & & $\begin{array}{l}\text { Right MR and LR exploration, scar } \\
\text { excision, adhesiolysis, temperance } \\
\text { ligament separation }+5 \mathrm{~mm} \text { of MR } \\
\text { recession and LR reset,In addition, } \\
\text { adhesion release between LR and IO. }\end{array}$ & $\begin{array}{l}\text { Hirschberg test: } \\
\text { ortho }\end{array}$ & -4 \\
\hline 9 & $-40 \mathrm{~L} / \mathrm{R} 9$ & & $\begin{array}{l}\text { Release of adhesions around the left MR } \\
\text { muscle, scar removal, temperance } \\
\text { ligament separation }+3 \mathrm{~mm} \text { of MR } \\
\text { shortening and } 7 \mathrm{~mm} \text { of LR (contractures) } \\
\text { recession. }\end{array}$ & $\begin{array}{l}\text { Hirschberg test: } \\
\text { ortho, no diplopia, } \\
\text { adduction normally }\end{array}$ & +2 \\
\hline
\end{tabular}




\begin{tabular}{|c|c|c|c|c|c|}
\hline No. & $\begin{array}{l}\text { Prism } \\
\text { with } \\
\text { alternative } \\
\text { cover test, } \\
\text { Krimsky's } \\
\text { test(PD) }\end{array}$ & $\begin{array}{l}\text { Prism } \\
\text { with } \\
\text { Maddox } \\
\text { cross } \\
\text { (PD) }\end{array}$ & Surgical approach & $\begin{array}{l}\text { Postoperative } \\
\text { follow-up time } \\
\text { (3 months) }\end{array}$ & $\begin{array}{l}\text { Postoperative } \\
\text { squint } \\
\text { angles(PD) }\end{array}$ \\
\hline 10 & $-20 R / L 10$ & & $\begin{array}{l}\text { Scar around the right inferior rectus (IR) } \\
\text { resection, adhesion release. }\end{array}$ & $\begin{array}{l}\text { Hirschberg test: }-5^{\circ} \\
\text { Vertical strabismus } \\
\text { disappeared, right } \\
\text { IO normally,motion } \\
\text { normally }\end{array}$ & $-10 \mathrm{R} / \mathrm{L} 2$ \\
\hline 11 & $\begin{array}{l}\text { Front }+ \\
14 \mathrm{~L} / \mathrm{R} 7 \\
\text { Left } \\
+25 \mathrm{~L} / \mathrm{R} 10 \\
\text { Right } \\
-10 \mathrm{~L} / \mathrm{R}\end{array}$ & & $\begin{array}{l}\text { Tendotomy and myectomy of the left IO } \\
\text { muscle, release of adhesions around the } \\
\text { left LR muscle, scar removal, temperance } \\
\text { ligament separation + left LR reset } \\
\text { (adhesion separation between LR and IO } \\
\text { muscle, scar removal). }\end{array}$ & $\begin{array}{l}\text { Hirschberg test: } \\
\text { ortho, motion } \\
\text { normally }\end{array}$ & +2 \\
\hline 12 & $-20 L / R 8$ & & $\begin{array}{l}\text { Scar around inferior rectus excision, } \\
\text { adhesion release, temperance ligament } \\
\text { separation }+7 \mathrm{~mm} \text { of right LR recession }+ \\
3 \mathrm{~mm} \text { of IR recession. }\end{array}$ & $\begin{array}{l}\text { Hirschberg test: } \\
\text { ortho, diplopia } \\
\text { disappeared, } \\
\text { motion normally }\end{array}$ & -2 \\
\hline 13 & R/L13 & & $\begin{array}{l}\text { Scar around the right IR resection, } \\
\text { adhesion release, temperance ligament } \\
\text { separation }+8 \mathrm{~mm} \text { of IR shortening. }\end{array}$ & $\begin{array}{l}\text { Hypertropia of right } \\
\text { eye went worse } \\
\text { (had second surgery } \\
\text { of recession of right } \\
\text { superior rectus } \\
\text {,SR),diplopia } \\
\text { disappeared in } \\
\text { functional eye } \\
\text { position. }\end{array}$ & R/L3 \\
\hline 14 & +30 & & $\begin{array}{l}\text { Scar resection around right MR, adhesion } \\
\text { separation, temperance ligament } \\
\text { separation }+6 \mathrm{~mm} \text { of MR recession and } \\
7 \mathrm{~mm} \text { of LR shortening. } \\
\text { Scar resection around the left MR, } \\
\text { adhesion separation, temperance } \\
\text { ligament separation + } 9 \mathrm{~mm} \text { of MR } \\
\text { recession and } 6 \mathrm{~mm} \text { LR shortening. }\end{array}$ & $\begin{array}{l}\text { Hirschberg test: } \\
\text { ortho, diplopia } \\
\text { disappeared. } \\
\text { Right } \\
\text { abduction-2 } \\
\text { adduction-2, } \\
\text { Left } \\
\text { abduction-2 } \\
\text { adduction-2, } \\
\text { Face turn } \\
\text { disappeared }\end{array}$ & -2 \\
\hline
\end{tabular}

\section{Discussion}

Of acquired restrictive strabismus mainly because of extraocular muscle lesions occur around the eye or orbit organized adhesions or abnormal strips contain other restrictions affecting the normal rotation of the eye. Restrictive strabismus 
secondary to surgery is one of a variety of complications, it is due to injury, the wound dry and surgical ischemia and other reasons, resulting in extraocular muscle and its surrounding tissue adhesions, fibrosis, mechanically limiting eye movement, cause insurmountable diplopia, affect normal life and work of patients. Secondary restrictive strabismus should be differentiated from extraocular muscle paralytic strabismus. Restrictive strabismus can be caused by conjunctival scarring, fat adherence syndrome, or rectus muscle contracture,and so on[13]. The fat adherence syndrome is an important cause of restrictive strabismus after retina surgery and that this complication can be minimized by avoiding surgical maneuvers that violate Tenon's capsule and expose extraconal fat. Many factors affected the longterm effects of strabismus surgery, which is very important reason is that the movement disorders caused by scar adhesions after surgery [4]. If restrictive strabismus in children early age, it will affect visual acuity and binocular vision development, and lead to monocular amblyopia in severe case. The treatment of secondary restrictive strabismus includes: prism, Botox injections or surgery [14]. Furthermore, some additional treatments were applied to avoid recurrency (subconjunctival and topical corticosteroids, amniotic membrane and therapeutic contact lens, 15).

In this study, strabismus surgical treatments including the full removal of the muscles around the scar, adhesiolysis, separation of medial and lateral ligaments and eye muscle surgery, have provided excellent results and patient's satisfaction. Among 14 patients, one case (No. 4) which surgery only including the full removal of the scar around the muscles, adhesiolysis, separation of medial and lateral ligaments, corrected small degree oblique; one case (No. 2) which the above surgery combined with antagonistic muscle surgery, diplopia in function eye position was disappeared after surgery; one case (No. 10) we only resect the scar around muscles, decomposed adhesions, corrected strabismus. The other 11 patients were used the full removal of the scar around the muscles, adhesiolysis, medial and lateral ligaments separated, and eye muscle surgery. During surgery we have found that limited scar around muscle is limiting eye movements, the duction and forced duction test is positive. After surgery, muscle adhesion has released and significant recovery of the eye movement is obtained. When combined with the corresponding eye muscle surgery, the amount of muscle operation with experience is very different with the conventional amount, therefore, it is convenient and helpful to have surgery under local anesthesia, which can observe eye position during the operation and improve the success rate of the corrective surgery. Six cases involved with medial rectus muscle surgery were found had closed adhesion of temperance canthal ligament and medial rectus, muscle function is limited severely. We believe that the first surgery failed to fully separate control ligament and medial rectus, results in dysfunction and eye movements restricted. Our experience suggests that the full separation between internal control canthus ligament and medial rectus plays a vital role in lifting restrictions and functional recovery for the medial rectus surgery.

In this study, 3 cases get restrictive strabismus secondary to strabismus surgery, preoperative examination indicates that the non-common factors have occurred in patients with severe strabismus and eye movement is not in place. It prompts us should operate carefully during strabismus surgery to reduce adhesions, including non-injury anatomy, muscle envelope to protect the integrity, complete hemostasis, minimize burning, to avoid interference Tenon's fat pad when cut, to avoid fat adhesion syndrome, but also to avoid over-stretch the extraocular muscles or muscle stripped from the surface of the eye [16], to avoid postoperative non-common factors. Such patients, if conventional surgery design, it is difficult to achieve the desired effect, we use the above procedure, the patient eye position corrected, eye movement improved.

\section{Conclusions}

In summary, the improper operation of eye surgery, can lead to secondary restrictive strabismus. The scar tissue ablation, adhesiolysis, separation of lateral and medial control ligament of muscle combined with muscle surgery can correct eye position, improve eye movements, eliminate diplopia and remove the compensatory head position, is an effective surgery choice. In this study, due to time constraints, sample collecting is small, which remains further study. 


\section{List Of Abbreviations}

TAO: Thyroid-Associated Ophthalmopathy

PD: Prism diopters

LR: Lateral rectus

IO: Inferior oblique

IR: Inferior rectus

MR: Medial rectus

SR: Superior rectus

IR: Inferior rectus

\section{Declarations}

Ethics approval and consent to participate

This study was approved by the Medical Ethics Committee of Peking University People's Hospital and conducted in accordance with the Declaration of Helsinki for research involving human subjects. The patients provided informed consent before the surgery, the parents or guardians of the patients under 18 years old provided informed consent before the patients underwent surgery.

Consent for publication

Not applicable

Availability of data and materials

The data analysed during the current study are not publicly available due to limitations of ethical approval involving the patient data and anonymity but are available from the corresponding author on reasonable request.

Competing interests

The authors declare that they have no conflict of interest.

Funding

This work was supported in part by the National Natural Science Foundation of China $(31427801,81470665)$ and Capital's Funds for Health Improvement and Research (2018-2-4086).

\section{Authors' contributions}

Lejin Wang designed the study. Lejin Wang did all the surgeries. Lili Guo, Zhihua Zhao and Zequn Miao recruited the participants. Qianru Ouyang and Xin Xu collected the subjects' research files. Lili Guo and Zhihua Zhao performed the data organization and analysis. Lejin Wang, Lili Guo and Zhihua Zhao wrote the manuscript. All authors critically revised and gave final approval to this manuscript.

Lili Guo and Zhihua Zhao contributed equally. 
Not applicable

\section{References}

1. Ela-Dalman N, Velez FG, Rosenbaum AL. Incomitant esotropia following pterygium excision surgery. Arch Ophthalmol. 2007; 125(3): 369-73. \

2. Rhiu S, Shim J, Kim EK, et al. Complications of cosmetic wide conjunctivectomy combined with postsurgical mitomycin C application. Cornea. 2012; 31(3): 245-52. \

3. Wright KW, Spiegel PH, et al. Complex strabismus: Restriction, paresis, dissociated strabismus, and torticollis. In: Handbook of Pediatric Strabismus and Amblyopia. New York, London: Springer; 2006. p. 323-387. 『

4. Wright KW. The fat adherence syndrome and strabismus after retina surgery. 1986; 93: 411-5. $》$

5. Dal Canto AJ, Linberg JV. Comparison of orbital fracture repair performed within 14 days versus 15 to 29 days after trauma. Ophthal Plast Reconstr Surg. 2008; 24:437-43. 『

6. Jordan DR, Allen LH, White J, et al. Intervention within days for some orbital floor fractures: The white-eyed blowout.

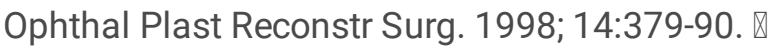

7. Mauriello Jr JA, Antonacci R, Mostafavi R, et al. Combined paresis and restriction of the extraocular muscles after orbital fracture: A study of 16 patients. Ophthal Plast Reconstr Surg. 1996; 12:206-10. \&

8. Biesman BS, Hornblass A, Liseman R, et al. Diplopia after surgical repair of orbital floor fractures. Ophthal Plast Reconstr Surg. 1996; 12:9-16. 『

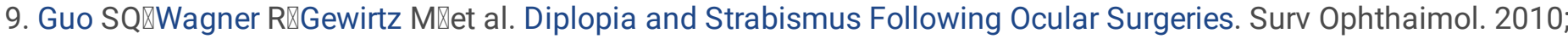
55: $335-8$.

10. Baxter SL, Nguyen BJ, Kinori M, et al. Identification and correction of restrictive strabismus following pterygium excision surgery. Am J Ophthalmol. 2019; 202: 6-14.

11. SE Avetisov, SS Danilov, AS Shaltynov. Strabismus and oculomotor disorders induced by injection anesthesia for cataract surgery. Vestn Oftalmol. 2020; 136: 197-203.

12. Campbell BC, Shipchandler TZ, Ting JY, et al. Ocular motility and diplopia measurements following orbital floor fracture repair. Am J Otolaryngol. 2021; 42: 1012-20.

13. Özkan SB. Restrictive problems related to strabismus surgery. Taiwan J Ophthalmol. 2016; 6:102-7.

14. Metz HS. Restrictive factors in strabismus. Surv Ophthalmol. 1983; 28:71-83.

15. Laria C , Shokida F, Tatarchuck $P$, et al. New diplopic restrictive strabismus as a sequela after conjunctival surgery for conjunctival lesions: a series of 3 cases, management and outcome. Binocul Vis Strabolog Q Simms Romano. 2012; 27: 113-21

16. Guo C, Wei RL. Advances in restrictive strabismus leads to the prevention of postoperative adhesions. Chin Ophthal Rles. 2005; 23: 222-4.

\section{Figures}




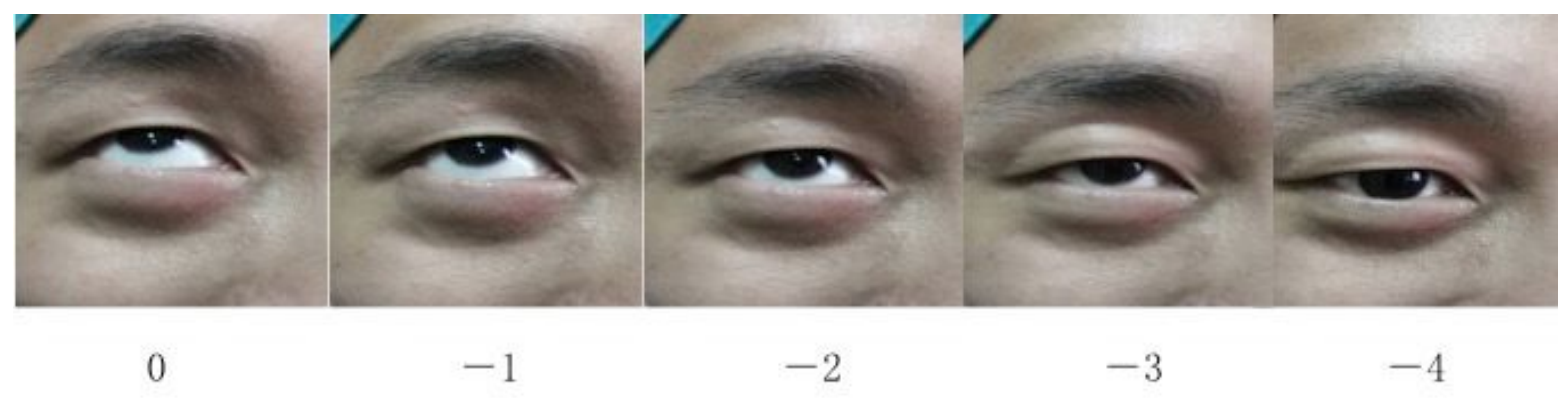

\section{Figure 1}

Motility grading scale in supraduction. Lengends: 0 indicates full motility, and -4 indicates an inability to cross the midline. The other 3 points on the scale represent further reduction in approximately $25 \%$ increments in between 0 and -4 . 